\title{
The functional development of a premature baby - case study
}

Rozwój funkcjonalny dziecka urodzonego przedwcześnie - studium przypadku

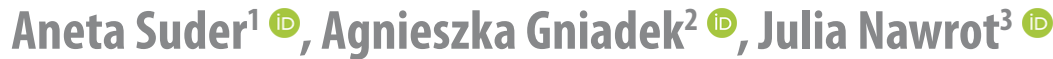

10ddział Kliniczny Neonatologii Szpital Uniwersytecki w Krakowie, ul. Kopernika 23, 31-501 Kraków/ Department of Neonatology of the University Hospital in Krakow

${ }^{2}$ Instytut Pielęgniarstwa i Położnictwa, Wydział Nauk o Zdrowiu, Collegium Medicum Uniwersytetu Jagiellońskiego, ul. Kopernika 25, 31-501 Kraków/ Institute of Nursing and Midwifery, Faculty of Health Sciences, Collegium Medicum of the Jagiellonian University

${ }^{3}$ Instytut Pielęgniarstwa i Położnictwa, Wydział Nauk o Zdrowiu, Collegium Medicum Uniwersytetu Jagiellońskiego, ul. Kopernika 25, 31-501 Kraków/ Institute of Nursing and Midwifery, Faculty of Health Sciences, Collegium Medicum of the Jagiellonian University

Słowa kluczowe:

CORRESPONDING AUTHOR/AUTOR DO KORESPONDENCJI:

Aneta Suder

Oddział Kliniczny Neonatologii

Szpital Uniwersytecki w Krakowie,

ul. Kopernika 23, 31-501 Kraków

e-mail: aneta.suder@doctoral.uj.edu.pl

\section{STRESZCZENIE ROZWÓJ FUNKCJONALNY DZIECKA URODZONEGO PRZEDWCZESNIE - STUDIUM PRZYPADKU}

Wprowadzenie. Intensywny rozwój nowoczesnych metod leczenia w neonatologii znacznie obniżył próg przeżywalności dzieci urodzonych przedwcześnie. Przedterminowe przerwanie procesu dojrzewania wszystkich układów w życiu płodowym wiąże się z ryzykiem powstania nieprawidłowości w rozwoju funkcjonalnym wcześniaków. Dzieci urodzone przedwcześnie narażone są w kolejnych latach życia na wiele problemów związanych z rozwojem motorycznym, poznawczym, społecznym i komunikacyjnym, dlatego aktualnie rośnie zapotrzebowanie na dokładniejsze śledzenie i badanie ich rozwoju. Wpływ urządzeń ekranowych na rozwój niemowląt i małych dzieci jest coraz większym problemem społecznym. Obecnie, dzięki rozwojowi nowych technologii cyfrowych, małe dzieci, a nawet niemowlęta dorastają w środowisku ekranu.

Cel pracy. Celem pracy była ocena rozwoju funkcjonalnego dziecka urodzonego w 29 tygodniu ciąży, w wieku kalendarzowym 28 miesięcy, z uwzględnieniem wieloaspektowej pracy rodziców.

wcześniak, rozwój funkcjonalny, technologia cyfrowa

\section{ABSTRACT THE FUNCTIONAL DEVELOPMENT OF A PREMATURE BABY - CASE STUDY}

Introduction. The intensive development of modern methods of treatment in neonatology has significantly reduced the survival threshold of prematurely born children. Early interruption of the maturation process of all systems in utero is associated with the risk of irregularities in the functional development of premature babies. Prematurely born children are exposed in the following years of life to many problems related to motor, cognitive, social and communication development, which is why there is a growing demand for more accurate tracking and research into their development. The impact of screen devices on the development of infants and young children is a growing social problem. Currently, thanks to the development of new digital technologies, small children and even infants are growing up in a screen environment.

Aim. The aim of the study was to assess the functional development of a 28 months old child born in 29 weeks of gestation, taking into consideration the multifaceted involvement and effort of parents.

Key words: $\quad$ premature baby, functional development, digital technology 


\section{INTRODUCTION}

Modern neonatal intensive care and treatment help keeping alive extremely prematurely born low-birth-weight infants. Preterm births occur in 5-18\% of pregnancies and it is the leading cause of neonatal death and the second one among children under the age of 5 [1]. Currently, preterm birth rate in Poland is $6 \%$ and it is similar to other European countries. Premature infant is defined by the World Health Organization as the one who was born between 22 a 37 weeks of pregnancy. Due to the variation of the premature newborns we describe: "late preterm" infants as those born from 34 to less than 37 weeks gestation, "moderate preterm" is designated from 32 to less than 34 weeks gestation, "very preterm" are infants born below 32 weeks of gestation and "extremely premature" infants are born before 28 weeks of gestation. Preterm infants are particularly vulnerable to a number of short- and long-term complications. The conditions that most often affect premature infants are: Respiratory Distress Syndrome (RDS), Bronchopulmonary Dysplasia (BPD), Intraventricular Haemorrhage (IVH), Necrotizing Enterocolitis (NEC), Retinopathy of Prematurity (ROP), hearing impairment, heart defects and low birth weight $[1,3]$.

Prematurity disrupts all maturation processes in utero and is associated with the risk of complications in further functional development. It may affect motor, cognitive, social and communicationdevelopment. Between 19981999, PREMATURITAS, a prospective study was carried out in Poland, including newborns born before 32 weeks of gestation in Warsaw. The study revealed that the most common neurodevelopmental disorder was cerebral palsy. The inversed relationship between gestational age and the prevalence of this disorder was observed. The incidence of cerebral palsy among children born before 32 weeks of gestation was $8-12 \%$ and for infants born before 28 weeks of gestation it was $49 \%$ [4]. Children born prematurely, especially with low birth weight, are more likely to have lower language skills than their peers born at full term. Delayed speech or language development has a significant impact on the child's cognitive, emotional and social functions, and thus may later have a significant influence on long-term achievements in education [5].

The development of new digital technologies has many useful applications, however, using electronic devices too early can negatively affect children's functional development. The impact of screen devices on infants and toddlers development has recently become a growing concern. Nowadays, even small children and infants grow up in a media-driven environment. The American Academy of Pediatrics (AAP) discourages media use for children younger than 18 months of age, while according to the World Health Organization (WHO) recommendations, this limitation should last for at least 12 months of a child's life [6]. However, the recent research on children's use of technology (2015) showed that all children aged 2 years have already been exposed to electronic media. The rate of children using electronic devices at least 1 hour per day rises from $14 \%$ at one year to $26 \%$ at their second birthday.
Parents often let their children play with mobile devices while doing shopping (60\%), homework (73\%), before sleep-time (29\%) or to make them calm down (65\%) [7].

Infants and toddlers before the age of 2 need social interaction with their caregivers to develop their cognitive, language, motor and socio-emotional skills [8] Using screen devices at this stage can have a negative effect on children's speech and language development. Parent's distraction with phones and mobile devices may affect verbal and nonverbal interactions, which are the key component of cognitive skills. It is also known that background television may affect parent-child interaction comparing to non-tv time. There is some evidence that background television is negatively related to the quality and amount of parent verbal communication with their children [9].

\section{AIM}

The aim of the study was to assess the functional development of a 28 months old child born in 29 weeks of gestation, taking into consideration the multifaceted involvement and effort of parents.

\section{MATERIALS AND METHODS}

Munich Functional Developmental Diagnostics (MFDD) was used to evaluate the psycho-motor development of a 28 months old child. The parents gave informed consent for their child's participation in a study. In order to obtain reliable and objective data, the test was conducted in calm surrounding and at suitable time. The mother of the boy was present throughout the whole time during the test. Standardized test materials were used to conduct the MFDD including: test pictures, picture book, shape sorter with 5 holes, five discs with drawings, box-shaped puzzle with four different blocks, wooden discs, sorter with colored cylinders, pyramid with discs, each in a different shape, a string with a stiffened tip and 3 wooden beads, wooden blocks, a doll, a music box with a crank, two small balls: light and heavy, a match box, a pencil, children's scissors, a small bottle with a screw cap, a small and a large ball with sponges, 4 identical flat containers, mesh belt, plasticine, A4 sheets of white paper, pencil. MFDD is a quantitative method which assesses early diagnosis of developmental deficits in small children. MDFF evaluates 7 developmental functions such as gross motor skills, fine motor skills, cognitive processes, speaking, understanding speech, social skills and independence.

\section{Case report}

The boy with the weight of $1080 \mathrm{~g}$ was born at 29 weeks of gestation via caesarian section with Apgar score 5 points (in the 1st and $3 \mathrm{rd}$ minute of life) and 8 points (in the 5th and 10th minute). Due to respiratory failure, he required non-invasive ventilation with continuous positive end-expiratory pressure CPAP (continuous positive airway pressure) up to 35 days of life. As a one-day-old infant he received surfactant using INSURE technique (Intubation-Surfactant-Extubation). Ophthalmologic 
examination for retinopathy of prematurity did not show any symptoms. Ultrasound examination did not detect any brain abnormalities. The patient was discharged from the hospital after 58 days. The parents accompanied their son in the hospital and worked on developing an early bonding between them and the baby. During the hospitalization in the Neonatal Intensive Care Unit, they regularly read books to him and used the method of kangaroo care with skin-to-skin contact. Reading and listening to audiobooks was the most common way of spending time together. In the first 28 months of his life they did not provide him with any electronic devices such as smartphone, tablet or television. He was allowed to listen to music but without looking at the screen. Other favorite activities included drawing, molding dough, puzzles and blocks. They also regularly walked and played in the playgrounds. As he was an only child, his parents often invited friends with other children in order to make the contact with his peers possible. In the first year of life the boy had regular motor development follow-up with a physiatrists. In this period and during his second year of life he did not require any specialized physiotherapy.

\section{RESULTS}

The boy, born at 29 weeks of gestation, who took part in the examination at 28 months of his chronological age had the following results in his psycho-motor development evaluation: his results in walking age, manual skillfulness, social development, speaking age and speech understanding were above medium of general population of children at the same age. His results in the area of perception age were at average level of development.
The evaluation of independence function showed the results below the average but no delays were diagnosed.

\section{CONCLUSIONS}

The wide range of disorders or delays which may occur in preterm born children both in the motor development and in the scope of learning or social behavior may be associated with antenatal complications such as: low birth weight, gestational age, intraventricular haemorrhage, respiratory distress syndrome. It is also known that the development results might be connected with non-medical aspects such as socioeconomic status, parents' educational level, model of parenting, their psychological well-being, family structure and functioning. All interventions that focus on both the parent-infant relationship and infant development are the most important for his development in short- and long-time perspective [10].

The boy, examined during the study at his 28 months of chronological age, not only equalized the level of development of his gross and fine motor skills, speech development, understanding and social development, but also showed development above the average known for population for his age. Based on the medical documentation and parent's medical interview we can assume that it is the result of appropriate treatment he received during hospitalization and the exceptional developmental stimulation provided by his parents later on. The lack of visual contact with electronic media devices influenced his extraordinary high score in speech development and understanding. Parents made a conscious decision to read books or develop their interaction instead of using screen media such as smartphones or television. This decision strongly supported the development of their child despite his extreme prematurity.

\section{Rozwój funkcjonalny dziecka urodzonego przedwcześnie - studium przypadku}

\section{WPROWADZENIE}

W ostatnich latach intensywny rozwój nowoczesnych metod leczenia w neonatologii pozwala utrzymać przy życiu noworodki skrajnie niedojrzałe, o niskiej urodzeniowej masie ciała. Przedwczesny poród występuje w przypadku 5-18\% ciąż, a jego powikłania są główną przyczyną śmierci noworodków i drugą w kolejności dzieci poniżej 5 roku życia [1]. W Polsce dzieci urodzone przedwcześnie stanowią ok. 6\% wszystkich urodzeń, podobnie jak w większości krajów europejskich [2]. Według WHO (Word Health Organization) wcześniaki to wszystkie noworodki urodzone pomiędzy 22. a 37. tygodniem trwania ciąży. Ze względu na duże zróżnicowanie grupy dzieci urodzonych przedwcześnie wyróżniamy podział na: „późne wcześniaki” tj. dzieci urodzone pomiędzy 34. a 37. tygodniem ciąży, ,umiarkowanie niedojrzałe noworodki” tj. urodzone pomiędzy 32. a 33. tygodniem ciąży, „,noworodki bardzo niedojrzałe” tj. urodzone poniżej 32. tygodnia ciąży, oraz „,noworodki ekstremalnie niedojrzałe” tj. urodzone poniżej 28 tygodnia ciąży. Noworodki urodzone przedwcześnie są szczególnie narażone na szereg powikłań krótko- i długoterminowych. Najczęstszymi powikłaniami będącymi skutkiem porodu przedwczesnego są: zespół zaburzeń oddychania (Respiratory Distress Syndrome, RDS), dysplazja oskrzelowo - płucna (Bronchopulmonary Dysplasia, BPD), wylewy dokomorowe (Intraventricular Haemorrhage, IVH), martwicze zapalenie jelit (Necrotizing Enterocolitis, NEC), retinopatia (Retinopathy of Prematurity, ROP), wady słuchu, wady serca, niedobór masy ciała $[1,3]$.

Przedterminowe zakończenie procesu dojrzewania wszystkich układów w życiu płodowym wiąże się z ryzykiem powstania nieprawidłowości w dalszym rozwoju funkcjonalnym. Dzieci urodzone przedwcześnie są narażone w kolejnych latach życia na wiele problemów 
związanych $\mathrm{z}$ rozwojem motorycznym, poznawczym, społecznym i komunikacyjnym. W latach 1998-1999 w Polsce przeprowadzono badanie prospektywne PREMATURITAS, którym objęte zostały noworodki urodzone przed 32 tygodniem ciąży na terenie Warszawy. Na podstawie oceny rozwoju dzieci do 2 roku życia wykazano, że najczęstszym problemem neurologicznym u wcześniaków jest mózgowe porażenie dziecięce, którego częstość występowania jest odwrotnie proporcjonalna do wieku ciążowego. Odsetek występowania mózgowego porażenia dziecięcego oscylował na poziomie 8-12\% wśród populacji noworodków urodzonych przed 32 tygodniem trwania ciąży i $17-18 \%$ u dzieci urodzonych przed 28 tygodniem ciąży [4]. Wcześniaki, głównie z niską masą urodzeniową, częściej wykazują mniejsze zdolności językowe w porównaniu do rówieśników urodzonych o czasie. Opóźnienie rozwoju mowy ma istotny wpływ na funkcje poznawcze, emocjonalne i społeczne dziecka, a co za tym idzie w późniejszym czasie może utrudnić obowiązki edukacji szkolnej [5].

Rozwój nowych technologii cyfrowych ma wiele przydatnych zastosowań, jednak używanie urządzeń zbyt wcześnie może szkodliwie wpływać na rozwój funkcjonalny najmłodszych członków społeczeństwa. Wpływ urządzeń ekranowych na rozwój niemowląt i małych dzieci jest coraz większym problemem. Obecnie dzięki rozwojowi nowych technologii cyfrowych małe dzieci a nawet niemowlęta dorastają w środowisku ekranu. Amerykańska Akademia Pediatryczna (American Academy of Pediatrics, AAP) zwraca uwagę, aby dziecko kategorycznie nie miało kontaktu $\mathrm{z}$ urządzeniami ekranowymi do 18 miesiąca życia, natomiast według WHO (World Health Organization) ograniczenie to powinno trwać przynajmniej do 12 miesiąca życia dziecka [6]. Badania Amerykańskiej Akademii Pediatrycznej z 2015 roku pokazują jednak, iż wszystkie dzieci w wieku 2 lat miały już kontakt z urządzeniami mobilnymi. Odsetek dzieci korzystających $\mathrm{z}$ urządzeń ekranowych minimum 1 godzinę dziennie wzrastał wraz z wiekiem i wynosił $14 \%$ w przypadku dzieci rocznych a $26 \%$ u dzieci dwuletnich, Rodzice najczęściej udostępniali dzieciom urządzenia mobilne w trakcie zakupów (60\%), prac domowych (73\%), a także w celu uspokojenia dziecka (65\%) lub przed zaśnięciem (29\%) [7].

Dzieci poniżej 2 roku życia, aby rozwinąć swoje umiejętności poznawcze, językowe, ruchowe i społeczno-emocjonalne potrzebują interakcji społecznych z bliskimi osobami [8]. Korzystanie z urządzeń ekranowych w przypadku dzieci poniżej 2 lat może mieć negatywny skutek w odniesieniu do funkcji rozwoju mowy. Pochłonięcie rodziców przez telewizję i smartfony może przyczynić się do zmniejszenia liczby i jakości interakcji rodzic-dziecko, które są kluczowe dla rozwoju umiejętności poznawczych. Wykazano także, że telewizja w tle zakłóca ciągłą zabawę dzieci już w wieku 12 i 24 miesięcy. Jednocześnie znacznie obniża się jakość i liczba interakcji między rodzicami a dziećmi w porównaniu do środowiska, w którym telewizja jest wyłączona. Dodatkowo telewizja w tle zmniejsza jakość i ilość języka rodzicielskiego skierowanego do dzieci [9].

\section{CEL PRACY}

Celem pracy była ocena rozwoju funkcjonalnego dziecka urodzonego w 29 tyg. ciąży, w wieku kalendarzowym 28 miesięcy, z uwzględnieniem wieloaspektowej pracy rodziców.

\section{MATERIAŁ I METODY}

Do oceny rozwoju funkcjonalnego dziecka w wieku kalendarzowym 28 miesięcy wykorzystano Monachijską Funkcjonalną Diagnostykę Rozwojową (MFDR). Rodzice badanego dziecka wyrazili pisemną zgodę na udział w badaniu. W celu uzyskania wiarygodnych oraz obiektywnych danych badanie zostało przeprowadzone w spokojnych warunkach i odpowiednim czasie dla dziecka. Badany chłopiec był w obecności swojej mamy. Do przeprowadzenia MFDR wykorzystano wystandaryzowany materiał testowy obejmujący: obrazki testowe, książkę z obrazkami, wkładankę z pięcioma okrągłymi otworami oraz pięć krążków z rysunkami, układankę w kształcie pudełka z czterema różnymi klockami, drewniane krążki, wkładankę z kolorowymi walcami, piramidę z krążkami, wkładanki każde w innym kształcie, sznurek z usztywnioną końcówką oraz 3 drewniane koraliki, klocki drewniane, lalkę, pozytywkę z korbką, dwie małe piłeczki: lekką i ciężką, pudełko z zapałkami, ołówek, nożyczki dziecięce, małą butelkę z zakrętką, małą i dużą piłkę z gąbki, 4 jednakowe płaskie pojemniki, pas z siatki, plastelinę, białe kartki papieru A4, ołówek. Monachijska Funkcjonalna Diagnostyka Rozwojowa ujmuje opóźnienie rozwoju w sposób ilościowy w 7 sferach rozwojowych takich jak: duża motoryka, sprawność manualna, percepcja, mowa aktywna, rozumienie mowy, rozwój społeczny oraz poziom samodzielności.

\section{Opis przypadku}

Chłopiec urodzony w 29 tygodniu ciąży, drogą cięcia cesarskiego, z masą urodzeniową ciała 1080 g. Po urodzeniu uzyskał w skali Apgar w kolejnych minutach życia: 5 pkt (w 1. i 3. min. życia) oraz 8 pkt. (w 5 . i 10 min. życia). Na skutek niewydolności oddechowej wymagał wentylacji nieinwazyjnej metodą utrzymywania ciągłego dodatniego ciśnienia końcowo-wydechowego w drogach oddechowych CPAP (continous positive airway pressure) do 35 doby życia. W pierwszej dobie życia otrzymał surfaktant metodą INSURE (intubacja + surfaktant + ekstubacja). W badaniu okulistycznym nie stwierdzono cech retinopatii wcześniaczej. W badaniu ultrasonograficznym nie stwierdzono zmian w obrębie mózgu. Dziecko zostało wypisane do domu w stanie dobrym w 58 dobie życia. Rodzice towarzyszyli chłopcu od chwili narodzin, dbając o tworzenie bliskiej więzi z synem. W okresie przebywania dziecka na Oddziale Intensywnej Terapii Noworodka rodzice regularnie czytali mu bajki i stosowali metodę kangurowania niemowlęcia w kontakcie „skóra do skóry”. Czytanie książek i słuchanie audiobooków było najczęstszym elementem spędzania wolnego czasu rodziców z dzieckiem. Chłopcu do 28 miesiąca życia kalendarzowego bezwzględnie nie udostępniano ekranu urządzeń 
cyfrowych typu smartfon, tablet czy telewizja. Dziecko słuchało jedynie utworów muzycznych $\mathrm{z}$ wymienionych urządzeń bez kontaktu wzrokowego z ekranem. Pozostałe ulubione aktywności dziecka to rysowanie, lepienie z ciastoliny, układanie puzzli oraz klocków. Dziecko wraz opiekunem regularnie spacerowało i korzystało z publicznych placów zabaw. Ze względu na sytuację, że chłopiec jest jedynakiem rodzice często zapraszali znajomych z dziećmi, w celu umożliwienia synowi kontaktu $\mathrm{z}$ rówieśnikami. $\mathrm{W}$ pierwszym roku życia chłopiec odbywał okresowe kontrole rozwoju motorycznego podczas wizyt u lekarza specjalisty w dziedzinie rehabilitacji. W tym okresie oraz w kolejnym roku życia dziecko nie wymagało specjalistycznego postępowania fizjoterapeutycznego.

\section{WYNIKI}

U badanego chłopca urodzonego w 29 tygodniu ciąży, w wieku kalendarzowym 28 miesięcy, uzyskano następujące wyniki oceny rozwoju funkcjonalnego. W zakresie wieku chodzenia, sprawności manualnej, wieku społecznego, rozwoju i rozumienia mowy chłopiec wykazał poziom rozwoju powyżej połowy ogólnej populacji dzieci w wieku 28 miesięcy. W odniesieniu do wieku percepcji (pojmowania zależności) chłopiec wykazał rozwój na poziomie średniej populacji dzieci w wieku 28 miesięcy. W obszarze zakresu samodzielności chłopiec uzyskał wynik poniżej połowy ogólnej populacji dzieci w wieku 28 miesięcy, ale nie wykazał opóźnienia w tym zakresie.

\section{PODSUMOWANIE}

U wcześniaków zaburzenia motoryczne, problemy w uczeniu się i zachowaniu mogą być związane z szerokim sepktrum czynników medycznych i/lub powikłań wcześniactwa np. niską masą urodzeniową, wiekiem ciążowym, krwotokiem śródkomorowym (IVH), zespołem zaburzeń oddechowych (RDS). Z wynikami rozwojowymi dzieci urodzonych przedwcześnie związane są również czynniki pozamedyczne takie jak: status społeczny, wykształcenie rodziców, styl rodzicielstwa, zdrowie psychiczne rodziców, struktura i funkcjonowanie rodziny Wszelkie interwencje, które koncentrują się zarówno na relacji rodzic-niemowlę, jak i na rozwoju dziecka, maja największy wpływ na rozwój poznawczy w perspektywie krótko- i średnioterminowej [10].

Badany chłopiec w wieku nieskorygowanym 28 miesięcy nie tylko wyrównał poziom rozwoju w zakresie dużej i małej motoryki, rozwoju i rozumienia mowy oraz wieku społecznego ale i osiągnął wyniki powyżej średniej populacji dzieci w tym wieku. Na podstawie dokumentacji medycznej dziecka, etapów leczenia, danych z wywiadu od rodziców o metodach postępowania w analizowanej sytuacji dziecka stwierdzono prawidłowość rozwoju w analizowanych zakresach. Osiągnięcie szczególnie wysokiego wyniku w zakresie rozwoju i rozumienia mowy chłopca może pozostawać w związku z brakiem wzrokowego korzystania z urządzeń ekranowych przez dziecko. Świadome nieudostępnianie dziecku powszechnych urządzeń, takich jak smartfon czy telewizja przez rodziców, a zastąpienie ich książką i interakcją rodzic-dziecko pozwola na kształtowanie rozwoju funkcjonalnego na właściwym poziomie pomimo skrajnego wcześniactwa.

\section{ORCID}

Aneta Suder (iD https://orcid.org/0000-0002-7313-0266 Agnieszka Gniadek (iD) https://orcid.org/0000-0003-4179-6730 Julia Nawrot (D) https://orcid.org/0000-0002-8651-6483

\section{REFERENCES/PIŚMIENNICTWO}

1. Chawanpaiboon S, Vogel JP, Moller AB. Global, regional, and national estimates of levels of preterm birth in 2014: a systematic review and modelling analysis. Lancet Glob Health. 2019; 7(1): e37-e46.

2. Czerwińska E. Czynniki wpływające na poród przedwczesny. Ginekologia i Perinatologia Praktyczna. 2018; 3(2): 52-57.

3. Świetliński J. Noworodek urodzony przedwcześnie - wcześniak [w:] Świetliński J. Neonatologia i opieka nad noworodkiem. Warszawa: PZWL; 2018, s.144-155.

4. Rutkowska M, PolakK, Seroczyńska M, i wsp. Długofalowa ocena rozwoju noworodków przedwcześnie urodzonych: doświadczenia własne (badanie PREMATURITAS) na tle wybranych badań europejskich. Perinatologia, Neonatologia i Ginekologia. 2010; 3(3): 175-180.

5. Vandormael C, Schoenhals L, Hüppi PS, et al. Language in Preterm Born Children: Atypical Development and Effects of Early Interventions on Neuroplasticity. Neural Plasticity. 2019: 1-10.

6. Wojtasik Ł, Dziemidowicz E. Urządzenia ekranowe w rękach dzieci w wieku 0-6 lat - zagrożenia, szanse, postulaty profilaktyczne. Dziecko Krzywdzone. Teoria, badania, praktyka. 2019; 18(2):106-119.

7. Bąk A. Jak małe dzieci korzystają z urządzeń mobilnych? Raport na podstawie danych zebranych od rodziców, Dziecko krzywdzone. Teoria, badania, praktyka. 2015; 14(3): 55-82.

8. Radesky J, Dimitri Ch. Media and young minds. Pediatrics. 2016; 138(5): 1-6.

9. Pempek TA, Kirkorian HL, Anderson DR. The effects of background television on the quantity and quality of child-directed speech by parents. Journal of Children and Media. 2014; 8(3):211-222.

10. Spittle A, Orton J, AndersonxPJ, et al. Early developmental intervention programmes provided post hospital discharge to prevent motor and cognitive impairment in preterm infants, Cochrane Database Syst Rev. 2015;11: 1-83.

Manuscript received/Praca zgłoszona do czasopisma: 19.02.2020

Manuscript accepted/Praca zaakceptowana do druku: 23.03.2020

Translation/Tłumaczenie: Julia Nawrot 